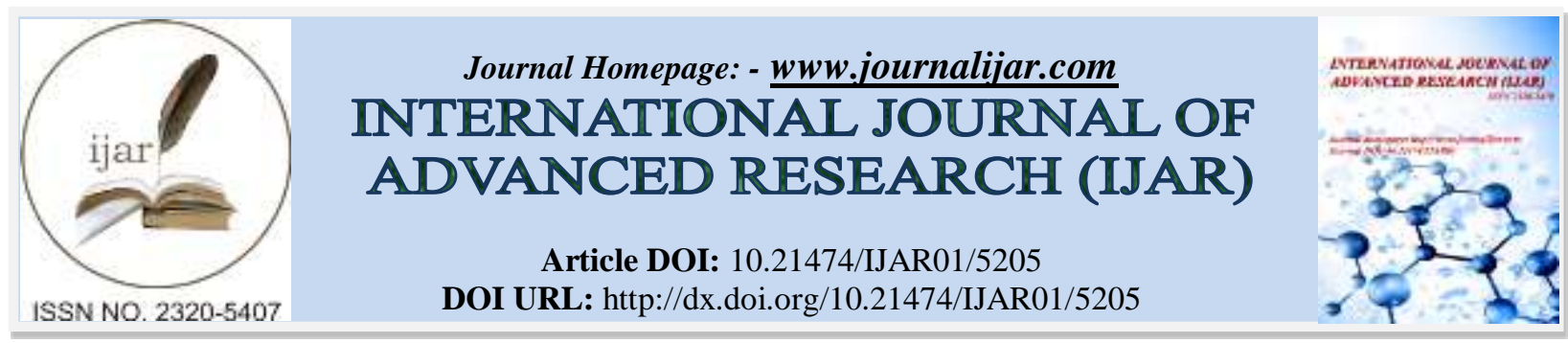

RESEARCH ARTICLE

\title{
THE EFFECT OF COMPETING ABILITY AND THE ROLE OF TRIPLE HELIX MODEL ON PERFORMANCE OF MICRO-SMALL-MIDDLE ENTERPRISES IN SIDOARJO REGENCY.
}

Rusdi Hidayat Nugroho and Eddy Poernomo.

Lecturer Program of Business Administration Science - UPN Veteran East Java.

\section{Manuscript Info}

Manuscript History

Received: 18 June 2017

Final Accepted: 20 July 2017

Published: August 2017

Key words:-

Competing Ability, Triple Helix Model, and MSME Performance.

\begin{abstract}
The objective of this research is to understand the effect of competing ability and the role of Triple Helix Model on performance of microsmall-middle enterprises (MSME) in Sidoarjo Regency. Research population includes all MSME in Sidoarjo Regency. The sample of research is owner and manager of Sidoarjo Regency MSME counted for 30 respondents. Data analysis technique is using Partial Least Square (PLS) supported with Software Smart PLS 2.0 M3. In this research, PLS is a method to construct the possible models the author can predict if involving too many factors. PLS can be used as a confirmation of theory, and also be useful to develop a relationship across variables which its theoretical base is lacking previously. The proposed hypothesis can also be tested with PLS. Result of research indicates that competing ability delivers a meaningful contribution to MSME performance. Triple Helix Model however does not have meaningful contribution to MSME performance.
\end{abstract}

Copy Right, IJAR, 2017,. All rights reserved.

\section{Introduction:-}

Indonesia has the greatest number of MSME in the world since 2014. The number still develops and the growth is persistent in 2016. Productive age population becomes higher in number compared to the available job. This condition forces youths to start their own business. Most of them enter the sector of Micro-Middle-Small Enterprises (MSME). In 2014, there are 57.9 millions MSME entrepreneurs, and in 2016, the number increases. Today, MSME has contributed to Local Gross Revenue by $58.92 \%$ and labor absorption by $97.30 \%$.

MSME has been the economical backbone of Indonesia and ASEAN. Around 88.8-99.9\% of enterprises in ASEAN are taking a form of MSME with labor absorption reaching 51.7-97.2\%. Therefore, international cooperation between Indonesia and ASEAN countries for the development and resilience of MSME becomes an important priority. ASEAN Economic Community (AEC) has been prevailed since the beginning of 2016, and as a result, MSME entrepreneurs of Indonesia must compete with their counterparts from other ASEAN countries.

Problem faced by MSME entrepreneurs in East Java, especially in Sidoarjo Regency, is no longer related with capital, but it concerns with competing ability of their product. Entrepreneurs find difficulty to improve their competing ability in producing highly-valued products. Their competing ability is low because they lack of knowledge about market and they do not have adequate accessibility to the market, either domestic or global. As a consequence, MSME entrepreneurs are hardly developed, and difficult to maximize their productivity. 
Processed-food MSME gives a distinctive marker to Sidoarjo Regency. However, the innovation on food product does not have strong competing ability because the food, including sate bandeng and emping pedas, is still produced and packed in manual and traditional ways. Lacking of knowledge and skill, and also conservative posture in holding ancestral tradition, are becoming factors constraining the competing ability of food entrepreneurs, at least in giving attractive package and more innovative flavors. The government of Sidoarjo Regency have put this problem into attention and consideration, and it already develops a program to encourage entrepreneurs to develop innovative capacity without harming their traditional manner. It is expected that this program helps Sidoarjo Regency's marker to have better competing ability in local or international markets.

The problem of MSME can actually be resolved fast if the government optimizes its role in empowering productivity of MSME entrepreneurs in Indonesia, especially those in Sidoarjo Regency. As observed by the author, this problem is also declared by the Head of The Official of Cooperation and MSME for Sidoarjo Regency. The location of research is Sidoarjo Regency and the focus is given upon micro-small-middle enterprises (MSME) in this Regency. The author attempts to identify how is the empowerment effort by the Government of Sidoarjo Regency through The Official of Cooperation and MSME for Sidoarjo Regency, in improving the capacity of MSME to deal with their problems.

Competing ability can develop from the capacity in managing and using resources and capitals available. Any companies with competing ability may have great power to compete against other companies. Products delivered by companies with competing ability have more advantages over those from the less competitive because consumers have great demand on products from the more competitive companies. Therefore, competing ability has always positive impact on improving MSME performance.

Triple Helix Model is a method of policy making based on innovation. This model explains how important is the creation of synergy among three poles, respectively academician, business, and government (ABG). First, academician is a part of scholar community, occupying important position in the college and research agency, and playing significant role in developing creative economic. The role of academicians/intellectuals in relation with innovation and creative ideas can give any companies the most leading position in the industry. Therefore, less surprisingly, role of academicians is needed by companies to take benefit from their creativity and also from their assistance in creating the leading products. Involving academicians should be the best decision made for MSME development. In supporting the success of MSME, academicians have several roles to be played: participating in developing and maintaining MSME potentials; providing innovative ideas and workforces; and providing important sources of information. It can be said that the role of academicians/intellectuals is influencing MSME performance. Second pole in Triple Helix Model is business people or entrepreneurs. This pole can also include business owner, new technology inventor, and even creative industry consumer. The role of entrepreneurs is quite relevant. Successful MSME is acknowledged from consumer satisfaction, and the resultant effect is the increasing number of orders. Final pole is the government, defined as a system of structures and organizations with various functions performed on certain bases to achieve national goal. It is not denied that government plays important roles to underline and support the success of other actors including private or businesses, educational institutions, and professionals. Roles of government involve acting as facilitator, regulator, and motivator. Other important roles played by government to ensure the success of MSME include being the constructor, impeller, regulator, and controller of the development; creating conducive climate to MSME; and restructuring and providing supporting facilities.

\section{Theoretical Base:- \\ Triple Helix Model:-}

Triple Helix Model is firstly introduced by Etzkowitz \& Leydersdorff as a method of policy making based on innovation. This model emphasizes on the importance of creating synergy among three poles, respectively academician, business, and government (ABG). By this synergy, it is expected that knowledge can produce innovation, meaning that knowledge would have economical potential or knowledge capitalization. Triple Helix comprises of $\mathrm{ABG}$ as three elements who always move in circulate to shape up knowledge space. In this knowledge space, these three elements have already equally compatible knowledge and understanding, which would drive them to form consensus space. At consensus space, they make agreement and commitment on several things which may direct them toward establishing innovation space that can be modified into creative product with economical value. Creative economic development model is a kind of building made of foundation, 5 pillars, and roof that empower to each other through its own function. The components of creative economic building are explained as follows: 


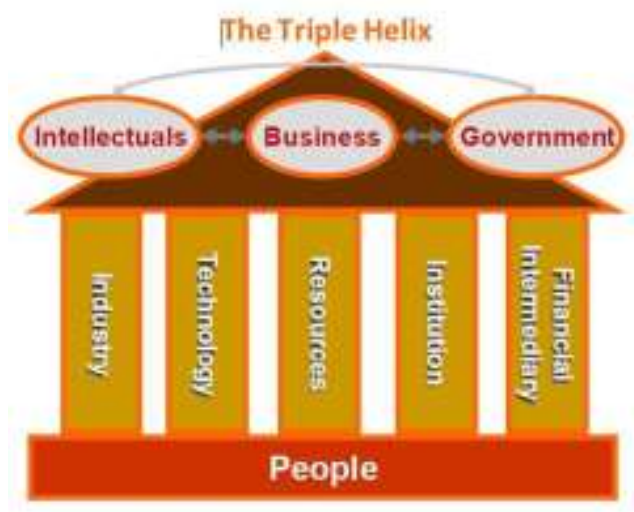

Source: Etzkowitz, H. The endless transition: A "triple helix"

\section{Foundation:-}

People (or Human Resource) is the main asset in the creative industry that becomes the common aspect in all creative industry sub-sectors.

\section{Five Main Pillars;-}

These pillars prop up the development of creative industry. It includes:

1) Industry. It is a band of companies moving into creative industrial sector.

2) Technology. It acts as a enabler to develop individual creativity into real work.

3) Resources. It is one of inputs other than individual's creativity and knowledge needed to carry on creative process; for example, natural resources and land.

4) Institution. It concerns with social order (including norms, values and laws) that regulates interaction between economical actors, especially those in creative industry.

5) Financial Intermediary. It refers to financial supplier agency.

\section{Roof:-}

The creative economic building is shaded by the interaction of Triple Helix involving academicians (intellectuals), business, and government as the main elements that drive the wheel of creative industry.

1) Academicians. They are also called intellectuals who occupy certain status at the formal, informal and nonformal education institutions, who have important role as the propeller of creation of science and ideas, and who become the source of creativity and other potentials among Indonesian human resource.

2) Business. It is mostly related with entrepreneurs who must transform creativity into an economical value.

3) Government. It acts as facilitator and regulator in such way that creative industry will grow and develop.

Government and governance are defined differently. Government refers to an organization or an instrument, while governance is about task or function. In narrow sense, government is around executive agency. In wide meaning, government entails some national instruments involving organizations, bodies, or agencies. All these instruments perfom some activities to achieve national goals. By this definition, government is also made of legislative, executive, and judicative agencies.

Governance, in narrow sense, is related with any activities, functions, tasks, and duties conducted by executive agencies to achieve national goals. Governance in wider sense is concerning with organized activities which its presence derives from sovereignty and independence but those must be implemented based on national principle, and also on the interests of citizen, population, and region, to achieve national goals (Haryanto et al, 1997:2-3). Deductively, it can be concluded that government and governance are developed to implement various operational functions to achieve more abstract national goals which usually settled constitutionally. Some of these functions are implemented differently by different social system, at least with different ideology. As a consequence, it ends into a different governance system, which more concretely represented by two extreme poles, respectively totalitarian regime (socialist) and democratic regime. Such disperse of power, according to Leslie Lipson, is one of five big issues in the political process (Josef Riwu Kaho, 2001:1). Local government is the consequence of such power dispersion.

Triple Helix affects MSME performance. The synergy created by academicians (intellectuals), business and government has played meaningful role in improving MSME performance (Puja Astawa, 2010). 
In economic, Triple Helix system becomes the umbrella that connects academicians (intellectuals), business, and government into creative economic blueprint. Three members of the helix are the driver behind the birth of creativity, idea, knowledge and technology which are critical for creative industry. Close relationship, sharedsupport, and mutualism symbiosis between helix members are providing base and pillars needed by sustainable economic model to improve MSME performance (Leydesdorff, L. and H. Etzkowitz, 1996).

Nowotny et.al. (2001) have suggested six indicators from which Triple Helix in certain industry can be the source of sustainability. These six indicators are Regulation and Protection, Knowledge, Research and Technology, Community Empowerment, Business Ethics, and Corporate Responsibility.

\section{Research Hypothesis}

As shown by overview, the hypothesis of research is described as follows:

1. Competing ability is positively and significantly influencing MSME performance.

2. Triple Helix role is positively and significantly influencing MSME performance.

\section{Method Of Research:-}

Operational definition is a term given to research's observation object which is understood based on definable or observable characteristics. Operational definition of each research variable is described as following:

I. Competing Ability (X1)

Competing ability is a benefit strategy of the company in making itself more effective in winning the market. Some indicators determine the success of competing ability (Barney, 1991 \& Grant, 1991).

Valuable (X1.1) is a resource that bestows competing ability because it gives rare value to company after it successfully exploits opportunities or neutralizes threats of external environment.

Inimitability (X1.2) is a resource that gives value to company only if other company does not own it or does not acquire relevant competence.

Durability (X1.3) is a resource giving the company a competing ability because the company successfully holds out the competitors, survives during resource obsolescence and time-based depreciation, or any problems that reduces competing ability.

Transferability (X1.4) is a resource giving the company easier accessibility to resources and competences owned by competitors or those beyond competitors, which then increases company's competing ability in term of cost or benefit based on the available process technology.

\section{Triple Helix (X2):-}

Triple Helix is a concept used to explain the relationship of three elements (academicians, business, and government). Triple Helix Model shows the coordinate of symbiosis (shear) of each element. In this model, each element is a stand alone entity and has its own role although they make a synergy. The indicators of Triple Helix are explained as follows (Nowotny et.al., 2001):

Academicians (X2.1)

Knowledge Transmission (X2.1.1). Knowledge is a key factor behind the success of MSME development.

Research and Technology (X2.1.2). It is central activity that must be done in developing innovation and technology. Business (X2.2)

Business Ethics (X2.2.1). It is about how to do the business with due process. It covers all aspects of individual, company, and also community. Business Ethics in the company can produce values, norms, and entrepreneurial behavior that allow entrepreneurs in building fair and healthy relationship with customers.

Corporate Responsibility (X.2.2.2). It means that business is done with adequate transparency and by respecting values of morality and acknowledgment. 


\section{Government (X2.3):-}

Regulation and Protection (X2.3.1). The government makes regulations to create orderliness, to fulfill needs and interests, and to be a part of governmental policy to protect industry.

Community Empowerment (X2.3.2). It is done by giving community a consulting service about how to implement business as it should be.

\section{MSME Performance:-}

MSME performance is a rate of achievement from comprehensive marketing activity done by company or organization. It is measured by following indicators (Voss \& Voss, 2000; and Kotler, 2002).

Customer Growth (Y1) is an increasing rate of customers for the goods or sales provided by the industry.

Sale Growth Rate (Y2) is the rate of sale that has increased if compared to previous period.

Marketing Scope (Y3) is the extend of marketing region for goods or services.

The population is the area of generalization. It comprises of objects or subjects with certain qualities or characteristics determined by the author to be learned and also from which the conclusion is to be drawn (Sugiyono, 2004:72). The population of this research includes all MSME in Sidoarjo District, Sidoarjo Regency.

The sample is a subset of population unit available. Technique used in PLS is resampling and bootstrapping (Geisser $\&$ Stone, 2001). The determination of sample size in PLS is described as following:

Ten times from the number of formative indicators (by disregarding reflexive indicators).

Ten times from the number of structural path in inner model.

Sample size: small size is about 30-50 respondents, while large size includes more than 200 respondents.

The sample of research includes owner and manager of Sidoarjo Regency MSME counted for 30 respondents.

Analysis Technique and Hypothesis Testing:-

Data are analyzed to help the author to draw a proper conclusion. Therefore, it is important to use analysis technique that is suitable with research objective and that also useful for hypothesis testing.

Data analysis technique is Partial Least Square (PLS) supported with Software Smart PLS 2.0 M3. PLS is a method to construct models that are possible to predict when too many factors are involved. PLS is initially developed by Wold as general method to estimate path model using latent variable and Multiple Indicator. PLS is also powerful analysis method for estimating indeterminancy factor because it does not assume data with certain scale measurement, and most important, it only needs small sample size. In the beginning, Partial Least Square comes from social science (economical science) (Herman, Wold, 1996). This model is developed as the alternative situation where theoretical base for model construction is week or if available indicators do not meet the need for reflexive measurement model. PLS can be used as a confirmation of theory, and also be useful to develop a relationship across variables which its theoretical base is previously lacking, or also meaningful for hypothesis testing (Anggraini, 2010).

\section{Hypothesis Testing:-}

Hypothesis testing ( $\beta$ and $\mathrm{Y}$ ) was done with resampling and bootstrapping methods suggested by Geisser and Stone. Test statistic used in this case is t-statistic or t-test. Statistic hypothesis includes as following:

Statistic hypothesis for outer model

$\mathrm{H} 0: \lambda \mathrm{i}=0$ versus

$\mathrm{H} 1: \lambda \mathrm{i} \neq 0$

Hypothesis for inner model: exogenous latent variable against the endogenus:

$\mathrm{H} 0: \lambda \mathrm{i}=0$ versus

$\mathrm{H} 1: \lambda \mathrm{i} \neq 0$

Resampling method enables data to have free distribution, reduces the need for assuming normal distribution, and removes the need for large sample (minimal sample counted for 30). Test is performed with t-test. If $p$-value $\leq 0.1$ with alpha $10 \%$, the finding would be significant, and otherwise, it is not significant. If hypothesis testing for outer model provides significant result, it means that indicator can be used as the instrument to measure latent variables. If 
hypothesis testing for inner model gives significant result, there is meaningful effect of one latent variable to another.

\section{Result And Discussion:- \\ Reliability Test:-}

Composite reliability is an index that shows to what extend which a measuring tool can be trusted or reliable. If a tool can be used twice to measure similar symptom and the measured result is relatively consistent, then the tool is called as reliable. In other words, reliability indicates how consistent is the measuring tool in measuring similar symptom. Complete result is shown in the following table:

Table 1:- Data Reliability

\begin{tabular}{|l|l|}
\hline & Composite Reliability \\
\hline COMPETING ABILITY (X1) & 0.595635 \\
\hline MSME PERFORMANCE (Y) & 0.776337 \\
\hline TRIPLE HELIX (X2) & 0.824494 \\
\hline
\end{tabular}

Source : Data are processed.

The reliability of certain construct is measured by composite reliability. Certain construct is reliable if its composite reliability stands above 0.70 , by then the indicator is called as consistent in measuring latent variable. Result of reliability test shows that the constructs (variables) of Triple Helix and MSME Performance have composite reliability bigger than 0.7 , and thus, both constructs are reliable. For competing ability, the composite reliability is smaller than 0.7 , then it is said that its reliability is low.

Testing on structural model is done by estimating R-Square value, which is also called as testing on goodness-fit of the model. Testing on inner model is done by examining R-Square value in the equation of latent variables. RSquare Value (R2) explains the extent to which exogenous variable (independent variable) in the model can explain endogenous variable (dependent variable).

\section{Causality Test}

Table 2:- Causality Test

\begin{tabular}{|l|l|l|l|l|l|}
\hline & $\begin{array}{l}\text { Path } \\
\text { Coefficient } \\
(\mathrm{O})\end{array}$ & $\begin{array}{l}\text { Sample } \\
\text { Mean }(\mathrm{M})\end{array}$ & $\begin{array}{l}\text { Standard } \\
\text { Deviation } \\
(\mathrm{STDEV})\end{array}$ & $\begin{array}{l}\text { Standard } \\
\text { Error } \\
(\mathrm{STERR})\end{array}$ & $\begin{array}{l}\text { T Statistics } \\
(|\mathrm{O} / \mathrm{STERR}|)\end{array}$ \\
\hline $\begin{array}{l}\text { COMPETING ABILITY (X1) } \rightarrow \\
\text { MSME PERFORMANCE (Y) }\end{array}$ & 0.515923 & 0.565492 & 0.239383 & 0.239383 & 2.155216 \\
\hline $\begin{array}{l}\text { TRIPLE HELIX (X2) } \rightarrow \text { MSME } \\
\text { PERFORMANCE (Y) }\end{array}$ & 0.215220 & 0.187251 & 0.182642 & 0.182642 & 1.178375 \\
\hline
\end{tabular}

Source: Data are processed.

Table above gives the following descriptions:

1. Competing Ability (X1) is influencing MSME Performance (Y) with path coefficient of 0.5159. This path is accepted because $\mathrm{T}$-statistic value $=2.1552$ is bigger than $\mathrm{Z} \alpha$ value $=0.10(10 \%)=1.645$. Hereby, the effect is significant (positive).

2. Triple Helix (X2) do not have an effect on MSME Performance (Y) as shown by path coefficient of 0.2152. This path is not accepted because T-Statistic value $=1.1783$ is smaller than $\mathrm{Z} \alpha$ value $=0.10(10 \%)=1.645$. The effect is non-significant (positive).

\section{Discussion:-}

The Effect of Competing Ability on MSME Performance:-

As stated in the result of research, first hypothesis that competing ability is influencing MSME performance is acceptable.

This finding is supported by Ginanjar Suendro (2011) who stated that competing ability and innovation as independent variables have simultaneous significant and positive effect on dependent variable of MSME performance in batik sector. First hypothesis is then supported. Partially (through t-test), it is proved that not all 
indicators of independent variables, such as competing ability and innovation, have significant and positive effect on dependent variable of MSME performance in batik sector. The relationship stating that competing ability has positive effect on MSME performance, thus, is also accepted because the result of test shows that competing ability has positive effect on MSME performance.

Other support is given by Potter (1997) who indicated the effect of competing ability on product success. This indication matches with the effect of competing ability on MSME performance. It grows consumer's purchase priority and increases the possibility of consumer's repurchase. Competing ability encourages company to be creative, at least giving several attempts to create sense of difference or unique on the eye of consumers, and also to convey messages to consumers in clear and directed ways. Creativity also facilitates company to produce sense of attraction among consumers toward the product, thus convincing consumers to look for the product.

As shown by explanation above, it can be stated that competing ability helps MSME to improve their performance.

\section{The Effect of Triple Helix on MSME Performance:-}

Second hypothesis indicating that Triple Helix is influencing MSME performance cannot be accepted.

The relationship stating that Triple Helix has positive effect on MSME performance is then not acceptable because result shows that one dimension in Triple Helix (government) does not have an effect on MSME performance.

It is said so because government dimension does not have great contribution to MSME performance. Most economists suggest that adequate political and legal orders are needed to deploy base conditions that allowing business to accumulate wealth and also that enforcing relevant institutions to be functional in regulating competition, in subjecting the market to discipline, in producing effective financial system, in providing labor market, and in protecting capitalist property right with legitimacy (Dunford, 2000; 148). Governmental indicator in Triple Helix Model has a little role in community empowerment, while dimensions of academicians and business have positive contribution. Although both owner or manager of Indonesian industry have believed that Triple Helix is a product of ABG's synergy (Academicians, Business and Government), but the owner mostly has some degrees of privacy in managing MSME performance. Therefore, the increase of Triple Helix would not influence MSME performance.

It is supported by Suparwoko (2010) who found that Triple Helix and innovation do not have significant and positive effect on dependent variable of Sugar-Palm MSME performance in Pacitan City. Second hypothesis, therefore, is not accepted in this case. Partially (t-test) of the research has proved that not all indicators in independent variables, including Triple Helix and innovation, do not have significant and positive effect on dependent variable of Sugar-Palm MSME performance in Pacitan City.

Triple Helix can be produced if three elements in ABG are continuously related on the interest of the owner or manager of the industry, or meaning that the industry is always satisfied with ideas or innovations suggested by ABG. Triple Helix emerges only if consumers feel satisfaction when they use the suggested innovation. Therefore, the three elements of ABG play important role in driving MSME industry to be more creative.

\section{Conclusion And Suggestion:-}

\section{Conclusion:-}

After performing research, and also collecting data from respondents and analyzing them, then it is concluded that: Competing ability is able to produce meaningful contribution to MSME performance.

Triple Helix cannot provide meaningful contribution to MSME performance.

\section{Suggestion:-}

The author gives several suggestions to be considered:

MSME performance should be improved, for instance, by posting advertisement in local television, and setting banners on certain spots by the street. It helps community to see and understand about MSME industry.

The existing products and services must be kept and maintained because it provides MSME industry with competing ability, including products with better quality and more variances.

The object of this research is limited to MSME in Sidoarjo District, Sidoarjo Regency. Therefore, the scope of next research should be extended to cover several regions. 


\section{References:-}

1. Adam Jr, Everett .E, Ronald .J. Ebert, 1992, Production and Operation Management, Prentice Hall International.Inc, Fifth Edition, New Jersey.

2. Anderson, J.C. and D.W. Gerbing, 1988, Structural Equation Modeling in Practice : A Review and Recommended Two-Step Approach, Psycological Bulletin. 103 (3) : 411-23.

3. Assauri, Sofyan, 2004, Manajemen Pemasaran, Cetakan Ketujuh, Rajawali Pers, Jakarta

4. Bentler, P.M. and C.P. Chou, 1987, Practical Issue in Structural Modeling, Sociological Methods and Research. 16 (1) : 78-117

5. Cravens, David W, 1996, Pemasaran Strategis, Terjemahan, Jilid 1, Edisi Keempat, Penerbit Erlangga, Jakarta.

6. Ferdinand, Augusty, 2002, Structural Equation Modeling Dalam Penelitian Manajemen, Edisi 2, Penerbit BP UNDIP, Semarang.

7. Hair, J.F. et. al. [1998], Multivariate Data Analysis, Fifth Edition, Prentice-Hall International, Inc., New Jersey.

8. Hartline, Michael D. and O.C. Ferrell [1996], "The Management of Customer-Contact Service Employees : An Empirical Investigation”, Journal of Marketing. 60 (4) : 52-70.

9. Kotler, Philip, 1997, Manajemen Pemasaran, Terjemahan, Jilid I, Edisi Keenam, Penerbit Erlangga Jakarta.

10. ----------, 2004, Manajemen Pemasaran, Edisi Milenium, Indeks, Jakarta.

11. ----------, dan Gary Amstrong, 1997, Dasar-Dasar Pemasaran.Jilid 1. Penerbit Prenhallindo, Jakarta.

12. Lamb, Hair dan Mc. Daniel, 2001, Pemasaran, Buku 1, Penerbit Salemba Empat.

13. Lupiyoadi Rambat, 2001 Manajemen Pemasaran Jasa Teori Dan Praktik. Penerbit Salemba Empat

14. Peter, Paul J. And Olson, Jerry C, 1996, Consumer Behavior : Perilaku Konsumen dan Strategi Pemasaran, Edisi Keempat, Jilid I, Penerbit Erlangga, Jakarta.

15. Sugiyono, 2004, Metode Penelitian Bisnis, Penerbit CV. Alfabeta, Sidoarjo

16. Swastha, Basu 1999, Manajemen Pemasaran, analisa perilaku konsumen, Edisi pertama, cetakan ketiga Yogyakarta.

17. --------, 2000, Azas-Azas Marketing, Edisi Ketiga, Penerbit Liberty Yogyakarta.

18. -----------, dan Tani Handoko, 2000, Manajemen Pemasaran, Analisa Perilaku Konsumen, Edisi Pertama, Cetakan Ketiga Yogyakarta.

19. Tabachnick B.G., 1996, Using Multivariate Statistics, Third Edition, HarperCollins CollegePublisher.

20. Tandjung, Widjaja, Jenu, 2004, Marketing Strategy,Edisi Pertama, Cetakan Pertama, Spirit 2004, Surabaya

21. Tjiptono Fandy, 2000, Manajemen Jasa, Edisi Kedua, Penerbit Andi Offset, Yogyakarta.

22. Leydesdorff, L. and H. Etzkowitz. 1996. Emergence of a Triple Helix of University-Industry-Government Relations, Science and Public Policy 23 (5): 279-286.

23. Leydesdorff, L. 2003. The mutua information of university-industry-government

24. relations: An indicator of the Triple Helix dynamics. Scientometrics 58 (2): 445-467

25. Leydesdorff, L. 2008. Configurational Information as Potentially Negative

26. Entropy: The Triple Helix Model. Entropy 10 (4): 391-410. 